\title{
CONSILIUM
}

Berkala Kajian Konseling Dan Ilmu Keagamaan

Avalaible at http://jurnal.uinsu.ac.id/index.php/consilium

ISSN : 2338-0608 (Print) | ISSN : 2654-878X (Online)

\section{Perbedaan Kreativitas Remaja Ditinjau Dari Peran Seks Androgini Dan Non-Androgini}

\author{
Rismar Julia Utami \\ Sekolah Tinggi Keguruan dan Ilmu Pendidikan Kerinci, Indonesia. \\ Korespondensi: rjutami@yahoo.co.id
}

\begin{abstract}
The study aims to determine the difference in adolescents 'creativity is reviewed from the role of androgynous and non-androgynous sex. This research uses quantitative methods. The research Data is obtained from sex role scale (BSRI) and Figural test of type B sub Test 3 (circle). The sample in this research is the students of XI SMA Negeri 4 Sungai Penuh. The number of samples in this study was 84 people. The results showed that there was no difference between the creativity of teenagers who had androgynous sex roles and teenagers who had non-androgynous sex roles $(P=0646, p>0.05)$. From the results of this study can be concluded that in addition to the sex role factors, psychological safety factor and psychological Freedom factor also determines the development of individual creativity.
\end{abstract}

Key Words: Creativity, Teen, Sex role.

Abstrak: Penelitian ini bertujuan untuk mengetahui perbedaan kreativitas pada remaja ditinjau dari peran seks androgini dan non-androgini. Penelitian ini menggunakan metode kuantitatif. Data penelitian diperoleh dari skala Peran Seks (BSRI) dan Tes Kreativitas Figural tipe B sub tes 3 (lingkaran). Sampel dalam penelitian ini adalah siswa-siswi kelas XI SMA Negeri 4 Sungai Penuh. Jumlah sampel dalam penelitian ini adalah 84 orang. Hasil penelitian menunjukkan bahwa tidak ada perbedaan antara kreativitas remaja yang memiliki peran seks androgini dan remaja yang memiliki peran seks non androgini $(p=0.646, p>0.05)$. Dari hasil penelitian ini dapat disimpulkan bahwa selain faktor peran seks, faktor rasa aman secara psikologis dan faktor kebebasan psikologis juga menentukan pengembangan kreativitas individu.

Kata kunci: Kreativitas, Remaja, Peran Seks. 


\section{PENDAHULUAN}

I

ndonesia menghadapi transformasi dari masyarakat agraris ke masyarakat industri dan nantinya ke masyarakat informasi di mana untuk pengambilan keputusan terbuka banyak kemungkinan pilihan dengan adanya perkembangan ilmu pengetahuan dan teknologi yang diikuti semakin lancarnya arus informasi dan komunikasi, membawa dampak tertentu bagi pola hidup manusia. Hal ini justru membawa permasalah an yang kompleks dan menjadi tantangan baik dalam masalah-masalah pekerjaan, pendidikan ataupun bidang yang lainnya. Satu-satunya cara agar dapat berkompetisi adalah dengan kreativitas yang juga merupakan tolak ukur sumber daya manusia (SDM), diharapkan peluang untuk hidup dan menghidupi selalu tumbuh dan berkembang dalam suasana serba sempit dan pengap. Tanpa kreativitas akan terjadi ritme yang monoton dan mudah ditebak akibatnya dalam perpacuan kehidupan akan selalu didahului oleh orang lain.

Memaknai kreativitas secara tepat masih terjadi beragam pendapat, menurut Guilford (dalam Suharnan, 2005) ciri-ciri kreativitas dibedakan menjadi aptitude traits dan non-aptitude traits. Ciri aptitude traits yang dikenal sebagai segi kognitif dari kreativitas ditandai dengan adanya kelancaran dalam mengemukakan gagasan, adanya keluwesan atau kemampuan mengubah pola berpikir yang lama dan menggantinya dengan pola pikir baru, originalitas atau kemampuan untuk menghasilkan respon-respon yang khas dan akurat dan elaborasi atau kemampuan untuk melengkapi dan menyampaikan ide atau gagasan secara terperinci dan detail terhadap suatu rancangan atau kerangka untuk menghasilkan bermacam-macam implikasi. Sedangkan ciri non- aptitude traits dikenal sebagai segi afektif dari kreativitas ditandai dengan mempunyai rasa ingin tahu, menghargai keindahan, berani mengambil resiko, senang mengajukan pertanyaan dan selalu suka tantangan atau pengalaman baru.

Setiap individu memiliki kemampuan kreativitas dalam derajat yang dan bidang yang berbeda-beda, potensi yang ada ini perlu untuk dipupuk dan dikembangkan sedini mungkin agar dapat diwujudkan. Untuk itu diperlukan adanya dukungan baik dari luar (lingkungan) maupun dari individu itu sendiri. Lingkungan dalam hal ini mencakup lingkungan keluarga, sekolah maupun masyarakat dan kebudayaan. Orang tua yang dapat memahami keberadaan anakanaknya akan menunjang potensi kreatif yang telah ada pada anak-anak mereka, dengan demikian dapat dikatakan bahwa peranan keluarga terutama orang tua sangat besar pengaruhnya bagi perkembangan seseorang.

Pembentukan konsep diri terhadap peran seks yang kaku dan konservatif atau tradisional yang terjadi pada masa kanak-kanak akan terus berlanjut hingga pada masa perkembangan berikutnya yaitu pada masa remaja, masa dewasa dan seterusnya. Pada dasarnya individu akan berperilaku atau mempunyai skematik tertentu terhadap peran seksnya tergantung dari bagaimana konsep dirinya 
terbentuk selama ini, seorang individu diyakininya akan merealisasikan dalam bentuk perilaku pada suatu atribut peran (Munandar, 2011).

Peran seks diartikan sebagai pengharapan sosial atas bagaimana individu itu seharusnya berperilaku, berfikir dan merasa sebagai laki-laki atau perempuan, untuk pengelompokkannya para ahli sepakat menyebutnya dengan istilah maskulin, feminin, androgini dan undifferentiated. Individu dikatakan maskulin apabila memiliki karakteristik agresif, mandiri, kompetitif, asertif dan lainnya. Individu feminin ditandai dengan karakteristik emosional, espresif, sensitif, simpatik dan sebagainya. Sedangkan peran seks androgini merupakan perpaduan antara nilai maskulin dan nilai feminin dalam skala yang tinggi. Sebaliknya, pada individu yang undifferentiated ditemukan karakteristik maskulin dan feminin dalam skala rendah (Ali, 2004).

Hilary M. Lips estetik (http://www.e-psikologi.com) mengartikan peran seks sebagai harapan-harapan budaya terhadap laki-laki dan perempuan, misalnya perempuan identik dengan perilaku lemah lembut, emosional dan keibuan sementara laki-laki dianggap lebih rasional dalam berpikir, jantan dan perkasa atau kuat. Ciri-ciri dan sifat tersebut dapat dipertukarkan misalnya ada laki-laki yang lemah lembut dan ada perempuan yang kuat dan perkasa, perubahan hal tersebut dapat terjadi kapanpun dan dimanapun.

Menurut Arasteh (dalam Hurlock, 2000) bahwa pada rentang masa remaja 13 sampai 18 tahun adalah periode kritis dalam perkembangan kreativitas dimana upaya dalam mendapatkan persetujuan dari teman sebaya terutama dari lawan jenis dalam mengendalikan pola perilaku remaja sehingga remaja dapat menyesuaikan kenyataan dengan harapan untuk mendapatkan penerimaan dari lingkungan sekitarnya.

Pendidikan formal di Indonesia hanya menekankan pada pemikiran yang konvergen dimana menuntut siswa untuk mencari jawaban tunggal yang paling tepat berdasarkan informasi yang diperoleh, siswa tidak diarahkan untuk dapat melihat suatu masalah dari berbagai sudut pandang, mencari sebanyak mungkin jawaban terhadap suatu persoalan atau untuk dapat memberikan solusi penyelesaian terhadap suatu masalah, kondisi ini kurang mampu menunjang fleksibilitas dalam pemikiran dimana merupakan salah satu aspek utama dari kreativitas. Dalam proses belajar mengajar siswa menerima begitu banyak instruksi terkait bagaimana melakukan sesuatu baik itu di sekolah, di Rumah, dan di dalam pekerjaan, sehingga siswa kehilangan setiap kesempatan untuk mengembangkan kreativitas. Kemampuan kreatif siswa ditekan oleh pendidikan dan pengalaman yang menyebabkan siswa tidak dapat mengenali potensi sepenuhnya dan mewujudkannya sehingga siswa tumbuh menjadi individu yang kurang terbuka kurang berempati terhadap lingkungan dan menyimpang dari yang konvensional. Siswa merasa lebih aman dan bergantung pada apa yang telah ada, 
sesuatu yang baru tidak terlalu disukai karena tidak biasa dan tidak dikenal (Munandar 2004).

Berkaitan dengan dunia pendidikan, siswa SMA yang berada pada masa remaja termasuk masa kritis dalam pengembangan potensi kreativitas, pemahaman ini dilandasi oleh pendapat Pikunas (dalam Ayu, 2007) bahwa pada masa remaja individu cenderung memiliki rasa keingin tahuan yang besar, memiliki keinginan untuk mendapatkan pengalaman baru dan melakukan eksplorasi. Steinberg (dalam Munandar, 2011) pada masa remaja individu dapat berpikir secara abstrak, serta mampu memikirkan kemungkinan-kemungkinan yang mungkin terjadi, dimana hal tersebut merupakan modal dasar bagi terwujudnya kreativitas. Mengenai peran seks dalam dunia pendidikan, pelajaran seks baik itu di SMP maupun di SMA terkait konsep peran laki-laki dan perempuan yang dimana peran seks feminin berorientasi pada keluarga perempuan dan lebih memperoleh kepuasan sebagai istri, ibu dan pengatur rumah tangga daripada keberhasilan dalam dunia pengusaha atau profesional yang merupakan peran seks maskulin atau laki-laki (Byrne dan Baron, 2004).

Berdasarkan hasil wawancara dengan beberapa siswa kelas XI SMA N 4 Sungai Penuh diperoleh gambaran bahwa siswa memiliki sifat keterbukaan terhadap pengalaman, bersedia mengembangkan diri tanpa terlalu terikat dengan peran seks yang diakui, hal tersebut disimpulkan dari pernyataan siswa bahwa saat sekarang adanya kesetaraan hak antara laki-laki dan perempuan. Menurut siswa saat ini mulai terlihat gejala perubahan peran pada perempuan, misalnya dalam mengasuh anak, perempuan tidak lagi diarahkan menjadi ibu rumah tangga tetapi juga sebagai wanita karier yang memiliki kesempatan yang sama dengan laki-laki.

Pendidikan untuk kaum perempuan juga sudah lebih baik sehingga wawasan perempuan lebih terbuka dan menjadi lebih cerdas, disamping itu dengan adanya teknologi memungkinkan perempuan melakukan pekerjaan-pekerjaan yang dulu hanya dapat dilakukan laki-laki, misalnya mengendarai bus atau alat-alat berat dan sebagainya, mengerjakan pekerjaan-pekerjaan baru yang dulu belum ada dan setelah ada sekarang dapat dilakukan baik oleh laki-laki maupun perempuan misalnya arsitek, operator, analis dan programmer komputer dan lain-lain. Pekerjaan rumah tangga yang dulunya adalah khas untuk perempuan sekarang dapat dilakukan oleh laki-laki dengan mudah misalnya berbelanja, mencuci dan pada umumnya juru masak adalah laki-laki. Hal tersebut sejalan dengan pendapat Munandar (2011) yaitu untuk dapat mengembangkan keempat aspek kreativitas (kelancaran, fleksibilitas, originalitas, dan elaborasi) diperlukan keterbukaan terhadap pengalaman, bersedia mengembangkan diri tanpa terlalu terikat dengan nilai sosial mengenai sifat dan perilaku tertentu untuk jenis seks tertentu. 


\section{METODE PENELITIAN}

Penelitian ini termasuk dalam penelitian komparatif. Pengambilan sampel dalam penelitian ini adalah purposive sampling. Sesuai dengan karakteristik subjek penelitian, subjek yang dikategorikan memiliki peran seks androgini berjumlah 27 siswa, non androgini 57 siswa, sedangkan undifferentiated 79 siswa diabaikan (tidak dimasukkan dalam analisis) dikarenakan peran seks undifferentiated secara ekplisit sulit dikategorikan. Sehingga diperoleh subjek penelitian yang sesuai dengan karakteristik berjumlah 84 orang siswa. Instrumen yang digunakan berupa metode testing dan skala.

Tes kreativitas figural tipe B sub tes lingkaran (tugas 3) dipergunakan untuk mengungkap kreativitas, sedangkan skala peran seks dipergunakan untuk mengungkap maskulin, feminin, dan androgini. Alat tes kreativitas yang digunakan yaitu Tes Kreativitas Figural (TKF) yang diadaptasi oleh Munandar dari Circle Test milik Torrance. Pemilihan alat tes TKF adalah karena alat tes tersebut mengukur kemampuan kognitif dari kreativitas. TKF dapat mengukur kemampuan dan membuat kombinasi antar unsur-unsur yang diberikan dengan memberikan bonus orisinalitas, selain itu TKF juga dapat mengukur semua aspek yang ada dalam tes kreativitas verbal (aspek kelancaran, keluwesan, dan kerincian), Tes kreativitas figural dapat digunakan pada anak dalam rentang usia 10-18 tahun. Tes ini terdiri dari empat baterai test yaitu dua verbal dan dua figural. Bentuk verbal terdiri dari verbal $A$ dan verbal $B$, dan bentuk figural terdiri dari figural A dan figural B. Tes kreativitas figural tipe B dari 3 sub tes yaitu :

1. Membuat gambar (Picture Construction)

2. Melengkapi gambar (Picture Completion)

3. Lingkaran (Circles)

Penelitian ini hanya menggunakan satu sub tes dari baterai sub tes kreativitas figural tipe B, yaitu sub tes lingkaran. Skala untuk mengukur perbedaan pola individual dalam hubungannya dengan peran seks dikembangkan pengukuran oleh Bem yang dikenal dengan nama Bem Sex-Role Inventory. Bem Sex-Role Inventory (BSRI) adalah suatu ukuran Bem (dalam Byrne dan Baron, 2004) tentang sejauhmana deskripsi diri seseorang dengan melibatkan karakteristik tradisional maskulin, feminin, atau keduanya (androgini), atau tidak keduanya (undifferentiated). Pemilihan skor dan median pemakaian BSRI menggunakan median-split, yaitu membagi dua bagian atas dasar mediannya (persentil 50) yang akan digunakan dalam menentukan tinggi rendahnya skor maskulin dan skor feminin. Dengan demikian setiap individu dapat dikategorikan pada salah satu dari empat peran seks yang ada (maskulin, feminin, androgini dan tak terbedakan) tanpa membedakan jenis kelaminnya (laki-laki dan perempuan). Pada skala ini terdapat 60 karakteristik sifat kepribadian. Dari 60 item itu, terbagi atas 3 subskala untuk 3 aspek yang masing-masing berisi 20 item, yaitu 20 item subskala maskulin

Sesuai dengan tujuan penelitian dengan variabel-variabel yang digunakan dan data yang diperoleh, maka teknik analisis data yang digunakan untuk pengujian hipotesis penelitian ini adalah teknik uji-t dua sampel independen dua sisi (independent-samples t-test). Alasan digunakannya teknik uji-t adalah dikarenakan penelitian ini bertujuan untuk menguji signifikansi perbedaan 2 buah mean yang berasal dari 2 buah distribusi (Hadi, 2004). 


\section{HASIL PENELITIAN DAN PEMBAHASAN}

Berdasarkan hasil pengolahan data yang dilakukan dengan menggunakan metode independent t-test diketahui nilai signifikansi sebesar 0.646 yang nilainya lebih besar dari pada taraf signifikansi $=0,05$. Artinya tidak ada perbedaan kreativitas yang signifikan antara remaja yang memiliki peran seks androgini dengan remaja yang memiliki peran seks non-androgini.

Tabel 1. Hasil Analisis t-tes Kreativitas Ditinjau dari Peran Seks Androgini dan Non Androgini

\begin{tabular}{llll}
\hline Kreativitas & t & Sig & Keterangan \\
\hline Androgini dan & $-0,461$ & 0,646 & Tidak Signifikan \\
Non Androgini & & & \\
\hline
\end{tabular}

Secara teoritis peran seks berpengaruh terhadap kreativitas, hal ini sesuai dengan pendapat Munandar (2011) bahwa kreativitas dapat juga dipengaruhi oleh peran seks yang dimiliki individu. Faktor peran seks yang fleksibel yang terdapat pada individu yang memiliki peran seks androgini yang mana peran seks ini merupakan pembauran yang berimbang antara sifat maskulin (mandiri, otonom, asertif dan sebagainya) dan sifat feminin (sensitif, lemah-lembut, penuh pengertian dan sebagainya).

Karakteristik yang terdapat pada peran seks androgini menawarkan jangkauan perilaku yang lebih luas untuk memperkaya pengalaman, serta memberikan kemungkinan sikap yang lebih fleksibel sehingga tidak membatasi perilaku individu termasuk perilaku kreatifnya. Sejalan dengan yang dikemukakan Macoby (dalam Monks, 2006) bila dikaitkan dengan kreativitas yang berlaku bagi siapa saja, baik laki-laki maupun perempuan maka didapatkan hasil dari berbagai penelitian bahwa individu yang terikat pada peran seks tradisional (peran stereotipe) menunjukkan kreativitasnya lebih rendah daripada individu yang relatif tidak terikat pada peran seks tradisional atau dengan kata lain memiliki peran seks yang sederajat (peran seks egalitarian).

Walaupun secara teoritis menunjukkan bahwa ada perbedaan kreativitas remaja ditinjau dari peran seks androgini dan non-androgini, namun dari hasil penelitian yang dilakukan tidak terdapat perbedaan kreativitas yang signifikan antara kedua peran seks tersebut. Hal ini dapat dilihat dari nilai $p=0.646$ dengan $p$ $>0.05$. hal ini kemungkinan terjadi karena adanya faktor lain yang lebih mempengaruhi adanya perbedaan kreativitas. Bisa jadi karena kurangnya sarana dan prasarana yang menunjang sikap kreatif baik dari lingkungan di rumah orang tua khususnya maupun pihak sekolah, sebab dari pengamatan diperoleh hasil bahwa lokasi tempat penelitian yang merupakan milik yayasan sehingga jumlah kelas yang ada serta lokasi yang terbatas tidak memungkinkan untuk pihak sekolah menyediakan peralatan-peralatan yang bisa menunjang perkembangan pendidikan 
dan kreativitas seperti laboratorium bahasa serta peralatan kesenian atau yang lainnya belum ada.

Wawancara dilakukan penulis dengan empat orang sampel yang memiliki kreativitas cukup sampai tinggi sebagai data tambahan/suplemen dengan kesimpulan sebagai berikut: bahwa sampel memiliki keinginan dan rasa ingin tahu yang besar terhadap hal-hal baru dan belum dikuasainya yang dapat dilihat dengan banyaknya les (seperti bahasa inggris dan komputer) dan ekstrakulikuler sekolah (seperti badminton, basket, bola kaki, bahasa jepang dan silat) yang mereka ikuti.

Hal tersebut sejalan dengan yang dikemukakan oleh Gunarsa (1999) bahwa pada masa remaja individu cenderung mempunyai keinginan yang besar untuk mencoba segala hal yang belum diketahuinya karena remaja merupakan sekelompok manusia yang penuh potensi. Pikunas (dalam Yusuf, 2006) menyatakan bahwa pada masa remaja individu cenderung untuk ingin tahu dalam segala hal, memiliki keinginan untuk mendapatkan pengalaman baru dan melakukan eksplorasi.

Adanya motivasi ingin tahu, mencoba hal-hal yang baru, dan mencari pengalaman-pengalaman baru merupakan ciri-ciri non-aptitude dari kreativitas, selain itu sampel juga memiliki lingkungan yang mendukungnya. Seperti adanya kebebasan dari orang tua dengan tidak membatasi kegiatan yang dilakukan sampel serta disediakannya sarana dan prasarana yang menunjang hal tersebut (seperti disediakan komputer di rumah). Sejalan dengan yang dikemukakan Munandar (2011) orang tua yang memberikan kepercayaan dan kebebasan kepada anak cenderung memiliki anak yang kreatif, mereka menerapkan pola asuh yang demokratis, tidak selalu mengawasi, dan tidak terlalu membatasi segala kegiatan si anak serta tidak terlalu cemas mengenai anak mereka. Lebih ditegaskan lagi oleh Wright (dalam Munandar, 2011) bahwa sebagai orang tua kita perlu memberikan lebih banyak keleluasaan bagi anak dalam memuaskan rasa ingin tahunya dan memberi kebebasan kepada mereka dalam bereksplorasi dan bereksperimen, serta lebih mementingkan pengalaman baru dari pada kesuksesan atau kegagalan sebab rasa takut gagal adalah penghambat utama dalam perkembangan kreativitas anak.

Keinginan dan rasa ingin tahu yang besar dalam diri remaja merupakan faktor pendorong internal dan dengan adanya dorongan eksternal seperti penghargaan orang tua atas prestasi anak serta sarana dan prasarana yang disediakan merupakan dua faktor pendorong yang dibutuhkan untuk mengembangkan kreativitas. Rhodes (dalam Munandar, 2011) hal di atas bisa merupakan kemungkinan penyebabnya, karena diketahui bahwa dalam usaha pengembangan kreativitas diperlukan adanya strategi 4-P (produk, pribadi, proses dan pendorong) yang mana kemungkinan faktor yang lebih bisa membedakan kreativitas, yaitu kurangnya sarana dan prasarana serta kurangnya motivasi dari orang tua merupakan bagian dari faktor pendorong bagi pengembangan kreativitas. Lebih lanjut Anastasi (dalam Munandar, 2011) adanya faktor pendorong merupakan 
manifestasi dari faktor kebebasan psikologis yang diperlukan individu untuk mengembangkan kreativitasnya.

\section{KESIMPULAN}

Berdasarkan hasil analisis data dapat diambil kesimpulan sebagai berikut: bahwa tidak ada perbedaan antara kreativitas remaja yang memiliki peran seks androgini dan non-androgini berdasarkan nilai signifikansi, dengan demikian hipotesis penelitian ini ditolak. Hasil wawancara dengan empat orang sampel dengan tingkat kreativitas antara cukup sampai tinggi diperoleh gambaran bahwa sampel memiliki motivasi untuk ingin tahu, mencoba hal-hal yang baru, dan mencari pengalaman-pengalaman baru, serta sampel juga memiliki lingkungan yang mendukungnya dalam pengembangan kreativitas.

\section{REFERENSI}

Ali, M. 2004. Psikologi remaja. Bandung: Bumi Aksara.

Ayu, Dwi N., \& Karina, I. 2007. Kajian konformitas dan kreativitas affective remaja. Jurnal Provitae, 3(3).

Byrne, D dan Baron, R. 2004. Psikologi sosial. Jakarta: Erlangga.

Hadi, S. 2004. Metodologi research I. Yogyakarta: Yayasan Penerbit Psikologi UGM.

Hurlock, E. B. 2000. Psikologi perkembangan: suatu pendekatan sepanjang rentang kehidupan. (edisi kelima). Terjemahan: Istiwidayanti \& Soedjarwo. Jakarta: Erlangga.

Monks, dkk. 2006. Psikologi perkembangan. Terjemahan: Siti Rahayu Haditono. Yogyakarta: Gadjah Mada University Press.

Munandar, S. C. U. 2004. Mengembangkan Bakat dan Kreativitas Anak Sekolah: Petunjuk bagi para guru dan orang tua. Jakarta: Gramedia Widisarana.

Munandar, S. C. U. 2004. Pengembangan kreativitas anak berbakat. Jakarta: Rineka Cipta.

Munandar, S. C. U. 2011. Kreativitas sepanjang masa. Jakarta: Pustaka Sinar Harapan.

Suharnan, M.S. 2005. Psikologi kognitif. Surabaya: Srikandi.

Yusuf, H. S. 2006. Psikologi perkembangan anak dan remaja. Bandung: Remaja Rosdakarya. 